\title{
Regulating the Private Rented Sector: Millennial Themes
}

\begin{tabular}{|r|l|}
\hline Journal: & Journal of Property, Planning and Environmental Law \\
\hline Manuscript ID & JPPEL-03-2018-0010.R1 \\
\hline Manuscript Type: & Article \\
\hline Keywords: & $\begin{array}{l}\text { Housing, Property Law, Regulation, Housing crisis, Private rented sector, } \\
\text { Private landlords }\end{array}$ \\
\hline \multicolumn{2}{|c}{} \\
\hline
\end{tabular}

SCHOLARONE ${ }^{m}$

Manuscripts 


\section{Regulating the Private Rented Sector: Millennial Themes}

The current housing shortage highlights both the importance and, indeed, the fragility of housing provision in England and Wales. Successive governments' focus has been to look to the market to resolve deficits in supply. Government's reliance on the private sector to provide housing, of necessity, invokes a use of law to do so and this in turn places property rights and interests at the fulcrum of state action. No mechanism is available to Government to lawfully alter private rights and interests without legal authority. To do otherwise would offend the law against 'takings' as it has no inherent right to expropriate interests. Thus, Government must 'regulate' to achieve its desired policy outcomes and this is secured through legislation and policy. With property in its sights, it is perhaps odd that there has been little if any discussion of how these activities impinge upon 'property' both as a legal fact in the construction of housing rights and its underlying conceptualization. Looking at the emergent trend in regulatory style deployed by successive governments is an interesting way to explore this.

The deference to market solutions to resolve housing dilemmas has grown with the advent of the New Public Management ideology where Government is an 'enabler' rather than a provider (Osborne and Gaebler, 1992). Yet, intervention by regulation has been a constant thread since the beginning of the twentieth century, if not before. The multiplicity of interpretations of what 'property' is, emphasises the contestability of the domain in terms of both policy and principle. This leads to conceptualizing property at the margins of both the relational (with the fundamental basis for any market grounded in the laws of supply and demand) and the tangible (how this relates to the asset itself). Property inevitably implicates people in their attachment to the 'thing' itself, as an actualization of self-regard or its representation and how this view, in turn, relates to others. The human dimension is integral to our understanding of the relational nature of the asset (whether in terms of entitlement or, alienability or its absence) and indeed the force of law (Derrida, 2002) in its recognition of those rights associated with it (whether property is real or personal) (Fox O'Mahony, 2006; 2013). Property and its laws make manifest the symbolic prize that we hold dear, represented by both notions of commodification and status, with the latter amplifying both power and dependency, pitting the 'haves' against the 'have nots' (this is particularly so in the context of landlord and tenant law). If 'property' is to be better understood, then we need to engage with not only those motivations or drivers, both individual and collective that inform the legal and indeed, the actual landscape, but also how those principles are affected by the policy choices made by Government, not least the regulatory ones. This paper reflects upon that interaction, focusing particularly on the relation between a use of regulatory tools deployed to deliver 
housing in the private rented sector (PRS) and the implications of those policies on how property rights are conceived. The paper applies regulatory theory to sketch out some themes present in the context of regulating the sector which tend to be ignored. Drawing on Selznick's valuable and often quoted definition of regulation as an exercise of, "sustained and focused control exercised by a public agency over activities that are valued by the community" (1985, p. 383), regulation for the purposes of this paper, is defined as the deployment of those practices relevant to controlling or shaping both the economic activity of renting out homes and the practices of adopted by landlords, so that they adhere to Government aims and objectives. These objectives, as will be shown, can extend well beyond the landlord and tenant relation. Furthermore, the attempts to control overall the configuration of the PRS and the activities adopted by landlords in the sector, do not always align. This tension is particularly apparent when the regulatory strategies adopted elide the very important need to protect occupiers and the promotion of housing availability in the sector. It will be argued that the misalignment between the two objectives can result in both an increasing pressure on the 'good' landlord to comply with the regulations to counterproductive effect, and in turn the availability of accommodation within the sector.

Much has been written by scholars on the significance of "the home" ranging from the realms of fiction (Robinson, 2008) to works in the social science disciplines including sociology and law (Desmond, 2016; Després, 1991; Mallett, 2004; and Easthorpe, 2004). The home carries a symbolism bound up with security, warmth and enjoyment and dignity, community and belonging (where insiders are recognised as being a part of the community and outsiders are those often displaced and beyond the status, visibility or indeed the help of the rest of society) as well as possession (Mellor, 1979, p.88; Fox O’Mahony, 2014; Roark, 2017). This is an area ripe for turf wars and contestation. Yet, we see from a political perspective a coalescence in worldview (Bright and Gilbert, 1995, p.28). In both politics and the media, the topical discussion is of the 'housing crisis', with a broad consensus across the main parties that, 'something must be done'. A typical Google search reveals over 241,000 'hits' for the "housing crisis" in England and Wales and 2.4million globally. During the 2017 election all parties made promises to address this. Labour's stated Manifesto policy remains to provide "secure homes for all" and the Liberal Democrats also made housing a major platform of their manifesto. The Government too has made an ongoing commitment to resolve this with the then Communities Secretary stating,

"We are determined to make housing more affordable and secure for ordinary working families and have a rental market that offers much more choice. We 
understand people are living longer in private rented accommodation which is why we are fixing this" (Javid, 2017).

Little wonder, therefore that housing is one of the hot topics on the political agenda. This is not just in relation to gaining the "youth vote", given the high percentage of the under 40's in the PRS. There is a widening interest in housing from both economic and regulatory angles too. The literature on regulation and its effectiveness or otherwise is a useful lens from which to view the PRS (as the Law Commission did in 2008). Established theory, as will be shown, signals the current regulatory trajectory as being highly problematic.

Economists, tend to view the provision of housing in the PRS through the heuristic of supply and demand - those wishing to find and live in decent accommodation at a fair and affordable price (although the two may not necessarily coincide) and those able to meet that demand, whether in the private sector or otherwise. Given the continuing shortage of public sector housing and indeed public finance constraint, reliance has, of necessity, fallen to the private sector to compensate for the deficits. And it is through that same market lens that successive governments have sought to focus their attention and formulate policy for regulating the PRS accordingly. The result has been to reconceptualise over time how landlords in the sector are conceived. Legal scholars, by contrast look to tenure; the manner in which the land is held and the relation between the parties in temporal terms in respect of it.

Ways of seeing property

Landlord and tenant relations remain a contested site of 'propertiness' (Gray, 1991). Contemporary housing law exists at the boundary between the public and the private, where state ambition encroaches upon private space. Hence interpretations of property and the applicable law are refined by instrumental state action that assumes a regulatory form. For some, the idea of property is, at its most basic, found in the notion of possessive individualism, where ownership by the individual - both of the 'thing' and indeed the person, is the key to human existence rather than the duties owed to wider society (Smith, 2012). By contrast, Gray and Gray's (2008, p.86) definition of property as a concept being in a perpetual state of flux can be seen here more clearly than in other areas. From both a relational and an exclusionary sense landlords' interests, like those of other property entitlements have come to be (re)defined according to social and economic rationales. In the given context, this is partly because of the liminal positioning of the tenancy within property space. The relation of the individual to her own labour, in the Lockean construction of property leads to accumulations and injustices that have tangible effects. This creates an inherent tension when considering housing law and may be an illustration of Prudhon's (1840, p.42) property as right and 
property as occupation disjunct. Macpherson (1978) would suggest that it is possible through liberal (as opposed to market) ideals to promote human flourishing. What is needed is different focus, one where a narrow interpretation of property law (such as that of enforcing the right to exclude (Merrill, 1998) is either fundamentally absent or only a given with the largesse of the state. This has profound consequences for how we view regulation in the context, in the sense of whether the two principles of property ownership and securing wider collective ends can be reconciled at both a theoretical and a practical level. For the former, conceptions of the law in private space predominate, while in the latter instance, regulation points to duties owed collectively (whether to other individuals, or to the state as means to secure policy objectives, which may or may not be for the benefit of other groups). Liberal theories of the market may prevail but do not necessarily sit well with regulation. Paradoxically the appeal to markets is used to justify interventions to overcome the wider effects of externalities adversely impacting upon a society. And yet these have as their scaffold a premise of rational individualism.

The tension between ownership and tenancy pits differing values of the home and in particular the commodified and the symbolic against one another. Ways of seeing property range from the individualistic through to the relational (Davies, 2007, p.2; Alexander, 1998, p.65; Singer, 2002) and have tended to reflect the tension between individual autonomy and community, most often articulated by reference to the pull of the exigencies of state and society. The sector contains significant segmentation from both tenant and landlord perspectives. In this site relations of dependency both individual (in the sense of those needing a home as against those able to provide accommodation) and collective (the acceptability of the claim to satisfy the general societal end of fostering cohesion and community, albeit that this is currently being placed under great strain) become amplified. This incremental confining of 'propertiness' to meet social ends through regulation illustrates quite vividly how property claims come to be reshaped by the exigencies of community (Renner, 1949). Two key aspects are in play here; the need to satisfy the justifiable and continuing need for housing and, linked to this, the policy and indeed ideological drivers framing the function of the public sector and its capabilities to deliver provision. For the latter the laws of the market dictate that the public sector only steers. A closer look at the structure of the sector reveals its physical fragmentation and is suggestive of why steering becomes so challenging.

Structuring the PRS 
The configuration of the sector highlights considerable fluctuations over time. Although historically in decline between 1914 and 1976, the demise of municipal housing signalled a resurgence in demand. This is confirmed in the National Dwelling and Housing Survey of 1977 statistics, showing occupancy of the sector at approximately 14\%. The supply of private rented accommodation in Great Britain dramatically fell from approximately $90 \%$ in 1914 to 11\% in 1999 (Balchin and Rhoden, 2002, p.105). Between 1971 and 1991, the size of the PRS fell from $22.5 \%$ of all households to 9\% with a revival during the 1990's (Joseph Rowntree Foundation, 2006). The property slump however, led to greater incursions into the sector (Joseph Rowntree Foundation, 1993). Currently there are more than 9m renters in the private sector with, according to Shelter (2017), the percentage of homes rented increasing by $69 \%$ since 2001. While tenants may have resident landlords, many will have assured shorthold tenancies of properties which can range from the 'ordinary' to the 'high-end'.

In 1981 private landlords housed $4.8 \mathrm{~m}$ people (Allen and McDowell, 1989, p.12). As the Housing, Communities and Local Government Committee inquiry into the private rented sector of 2017 identified, private renting is in the resurgence. It is known for example that between 2000 and 2014 the number of units rented privately in the UK rose by $125 \%$ (Scanlon and Whitehead, 2016). According to the Commons Select Committee Housing, Communities and Local Government Private Rented Sector and Draft Tenant Fees Bill launched 9th October 2017, the sector has grown from 1 in 10 households in 2004 to 1 in 5 households in 2016 with the under-40s making up $70 \%$ of households. In its 2006 Report, the Joseph Rowntree Foundation figures indicate that in 2001 11\% households were renting privately. A 2010 Government survey showed that $89 \%$ of landlords in England were private individuals and $98 \%$ of these owned fewer than 10 properties and $70 \%$ of all dwellings. This is the age of 'generation landlord' (Ronald and Kadi, 2017). It is known also that one in 10 adults in the UK owns multiple homes with the number of people with at least two properties having jumped 30 percent to 5.2 million between 2000-02 and 2012-14 (Resolution Foundation, 2017). Most are held by the "baby boomers" born between 1946 and 1965 (DCLG, 2010). Intergenerational disparity, (particularly inequity in purchasing power) is not the only source for concern. A considerable amount of the wealth accumulated from property is located within the South East and between the eras 1999-2001 and 2013-16, it would appear that the percentage of adults receiving income from property as landlords (whether commercial or residential) has doubled from 1.7 to $3.4 \%$ (ONS, 2016). A sample survey of 2,517 landlords in the UK undertaken by the Council of Mortgage Lenders in 2016 showed that $62 \%$ of landlords owned only one property, a figure extrapolated to account for $28 \%$ of the PRS (Scanlon and Whitehead, 2016). By contrast, the same sample study showed that 7\% of landlords owned five or more dwellings accounting for $38 \%$ of stock. This coupled with 
the ongoing decline in providing "affordable housing" has amplified the disparity between the propertied and those relying upon renting and, indeed, the reification of the home, particularly from the landlord perspective when 'home' undergoes the transformation into a high value asset. The fluctuations in stock contained in the PRS contribute to, but do not explain fully segmentation within the sector. To do so, reference should be made to that less than homogeneous group - the landlord.

(De)constructing the private sector landlord

The construction of the 'landlord' in law remains underdeveloped. Although we can all discern who one is, there are relatively few legal definitions. Most focus on defining the landlord and tenant relation or the tenancy itself, where one person, the tenant has the right to exclusive possession of the land of another, for a length of time (Bright and Gilbert, 1995, p.2). This points to the interest acquired by those taking the lease or tenancy; in itself inferior to that of the 'landlord. Leases mark the intersection of property and contract in law. The idea of a landlord invokes many different and, of course, human vagaries leading to a multiplicity of traits.

From a property law perspective, the "bundle of rights" vision, which has, to a degree, fallen out of favour, offers a useful lens for recognizing multiple interests that coexist both concurrently and /or sequentially. When looking at landlord and tenant relations, the right to use and the right to possess are fragmented and can potentially be dispersed across the social spectrum. This emphasizes the definite and indefinite duration of the right (Commons, 1893, p.92). In common parlance the landlord is associated with being the freeholder, with the tenant acquiring some form of lease. One concern is that such the bundle of rights approach allows for a "mutable relation" as between the landowner and the state (Merrill and Smith,2014, p. 683) too. Indeed, statute in addition to the common law have broadened the scope of landlord identity to include all those having superior interests, whether freehold or otherwise.

It is highly problematic to view landlords as a cohesive group having uniform aims and objectives (Allen and McDowell, 1989, p.5). Landlords may be motivated by profit above all else, while others may have more altruistic justification for renting out property. The heterogeneity in motive, intent and indeed geographical location, poses particular challenges for policy makers. The "owner-occupied landlordism" identified by Kemeny (1981, p.79) has grown with the emergence of both the accidental landlord (especially those inheriting property in times when the selling market is unstable) and those (often buy-to-let landlords) seeking to actively compensate for prevailing low interest rates, or present or future pension 
deficiencies, notwithstanding the relatively poor rate of return on investments of the type. Thus, individual landlords can have multiple motivations. Some may still perceive the property rented out as "their home", by reason of emotional attachment. They may, for example, have once lived there. Others (such as buy-to-let landlords) may see the activity as way of creating additional income streams (whether present or future). Further, given the variety of landlords present in the sector, it is plausible to think that not all will be model rational agents motivated purely by profit. For some it will be a full-time occupation and potentially a sole source of income, while for others being a landlord may be a hobby, a chore or a part-time necessity. Similarly the response to regulation will vary according to interest, knowledge and ability. The term, 'landlord' can illuminate as well as obfuscate. While being problematic, because of its connotation of uniformity in the sector (something that is empirically unsupported) seeing 'the landlord' as some form of cohesive group is a useful heuristic to deploy and is evidently how policy makers seem to view (or perhaps wish to view) the PRS. However as will be shown this can be disadvantageous to establishing regulatory effectiveness.

Besieging the castle? Eroding property (rights) through regulation.

The Blackstonian vision of property being that, "sole and despotic dominion" tends to a highly individualistic, liberal view (albeit one subject to limitations dictated by the state). The 'castle' metaphor drawn by Coke J in Semayne's Case (1604) emphasises the liberal paradigm. Peñalver (2006, p. 2973) in noting the metaphorical impenetrability of the 'fortress', points also to the idea of dominion referencing the dignity of ownership. Whether we adopt the metaphor of the castle as dominion or dignity, the wave of regulation within the private rented sector certainly challenges ideas of the dominion in property rights.

The existence of inequality in bargaining as between landlord and tenant can be traced historically and has been well-documented. As Singer (2002, 826-33) notes,

Tenants and landlords have unequal bargaining power because housing is a necessity and because of structural disparities between landlords and tenants associated with the fact that landlords own real property and tenants do not.

This has led to and justified protective legislation. It has not always, as will be shown improved tenants' position. Recall Nelken's pithy statement in (1983, p.22) that,

the application of universal standards to unequal parties necessarily produces unequal results.

The inequalities have as much to do with the shaping of property law as with the cultural symbolic themes surrounding the home. The landlord tenant relation, grounded as it is a 
within social and political context, impinges upon autonomy, equality and indeed how the 'person' and their 'home' come to be recognised in law. Not only does landlord and tenant law illustrate the 'weighting' of rights to use and access property, where notionally, relatively few restrictions on the capacities of the landlord (including who a private landlord can let her property to) exist, but it perhaps highlights continuing levels of tenant dependency far removed from an enlightened approach to basic need. The configuration of land law is such that there is little if no purchase for tenants to break into its domain. Historically, the existence of Blackstone's (1829, Bk 2 Ch 1) 'sole and despotic dominion' left no conceptual room for those dependent upon landlords for shelter, let alone the ability to assert their rights, because interests in land could never be subjugated to contractual entitlements alone without the support of the state. Tenants can only do so with the state's assistance in the form of law (most often regulatory law). This has resulted in a number of regulatory strategies, ranging from the reactive to the pre-emptive. State intervention remains however, highly problematic.

\section{Regulating landlordism}

Marxist ideology and nineteenth century liberal thought saw landlordism as a negative activity bound with notions of exploitation of those dependent upon the largesse - notional or real - of the landowner. As a consequence, the term "landlordism" acquired a pejorative meaning (Jackson 1885), connoting bad behaviour, dispossession and the parasitic benefits deriving from the labour of others often in times of colonialism (Lazarus, 1892). New landlordism (Ronald, Lennartz and Kadi, 2017) by contrast, connotes a reconfiguring of the sector, driven in part by an extended period of low interest rates, the perceived safety of investing in property as opposed to the stock market and the rise of buy-to-let. This was facilitated by the Housing Act 1988 provisions enabling easier recovery of properties and removing rent restrictions. New landlordism amplifies the dilemmas exposed by the market but focuses on the asset value of the landlord's interest. Tenant protection, such as it is, is to be delivered by regulation.

In regulatory terms, inroads have been made to address, in part, the imbalance between landlord and tenant. Although considerably far from recognizing that tenants within the sector are to be perceived in law as equals with their landlords, the strategies deployed demonstrate a shift from generalized (and largely anonymized) protection to that of proactive, 'categorized' and even individuated forms. Incrementally, statutory provisions have shifted the focus firstly by emphasizing housing conditions and then by seeking to turn attention to tenant protection in terms of security. Whilst regulation overall has shifted from 
laissez faire to protection (Bright and Gilbert, 1995, p. 12), current regulation of landlord behaviour, seeks to create, it is argued, a category of acceptable landlord by defining and confining those categorized as the 'rogue' landlord.

Looking back, we can discern policy and legislative shifts that have sought to alter the landlord and tenant relation and, perhaps more importantly the nature of landlordism. The act of regulating (by imposing rules, procedures and practices that have the intent if not the effect of altering behaviour) functions both at individual and collective levels. Regulation can reconfigure markets and sectors as is the case with pharma, media and financial services sectors, through both hierarchy - in the form of 'strong' independent oversight forms and the deployment of more consensual and collaborative forms. It can apply to both economic and more social sectors and can have the effect of promoting acceptable behaviours which in turn can protect those less able to effect change themselves by providing information, or indeed preventing unacceptable activity. It should not be forgotten that sometimes the process of regulation can have spillover or indeed counterproductive effects.

Historically, the PRS comprised many pre-1919 dwellings in poor condition. Chadwick's reforms culminating in the Public Health Act 1848 and subsequent legislation paved the way for concerted efforts being made to improve housing standards. Slum clearance both pre- and post WWII was targeted primarily at housing conditions (and thus the predominantly the private sector) with councils being given powers to demolish slums and undertake renewal. The moves coincided with the genesis of a welfare state from the late nineteenth century, and with it the provision of 'a land fit for heroes to live in' by way of Addison's Housing Bill. This gave impetus to the creation of council housing and further legislation providing for housing fitness standards. It may be fair to say that the approach was generalized and protective. The regulatory focus fell upon the sector as a whole. The housing improvement strategies that rehabilitated the PRS during the 1970's and 80's had a similar focus.

The rise of neo-liberalism and the orientation towards emphasizing market solutions rather than relying upon "big government" has radically shifted housing provision. The age of public sector provision in the form of council housing, so important in post-war Britain, now seems a distant vision. The private sector in its multiple forms has supplanted many of the roles and functions of municipal government and housing is no exception. The lifting of rent restriction by the Housing Act 1988 provisions, is an example of how market solutions were deployed to invigorate a sector and so increase availability by the erosion of tenant protection in terms of both security of tenure and rent protection. In late modernity, the availability and provision of housing rests heavily upon the ability of 'the market' to deliver solutions to 
complement and compensate for the failings of the public sector. Some are ideological others structural. In the PRS, tenants experience significant challenges in finding safe, secure and decent homes at affordable prices. Many are at the mercy of a market that presents barriers to entry, informational asymmetries and, perhaps paradoxically even from a neo-liberal perspective fails to achieve a sensible equilibrium in welfare outcomes overall. The problem is that as well as seeking to regulate an economic activity, policy makers also have to pay heed to the ideological, emotional and symbolic associations attached to landlordism, and indeed use the sector to secure much wider ideals that bear little relation to the objective of either tenant protection or the facilitating of housing supply. The result has been to deploy a mix of strategies. Some are reactive focusing on housing condition or tenant safety, others seek to create the ideally typical landlord, malleable to Government's will and sometimes securing policy objectives far beyond improving the landlord and tenant relation as will be shown below. Each will be considered in turn.

Housing conditions

Despite the sweeping approach of slum clearance, housing condition standards in the sector continue to be poor. The English Housing Condition Survey 2014-15 (2016) noted that, despite housing more households than the social rented sector, $29 \%$ of properties would fail the Decent Homes Standard, the non-statutory minimum standard applied to social housing. Although a reduction in the 2006 figure, where $47 \%$ of private housing would not meet the standard, this represented a rise in the failing condition of properties in the PRS from 1.2 to 1.3million, according to a House of Commons Library research briefing of 2016. The landlord's implied repairing obligation and the relatively confined duty relating to fitness for habitation (founded at common law and in the provisions of the Landlord and Tenant Act 1985, for example) provide for more focused and individuated forms of control. They rely primarily upon the tenant seeking legal redress ex post. This in itself is highly problematic. The Housing, Health and Safety Rating System introduced by the Housing Act 2004 (a successor to the housing fitness standard applied to unfit properties and risk-based in approach) gave powers to local authority Environmental Health Officers to undertake a risk assessment of hazards in residential housing and where these are identified on inspection a duty to take appropriate action. These measures are largely reactive, with sanctioning applying in the event of infraction and successful enforcement. They have been the object of criticism on the basis of inconsistent interpretation and enforcement by local authorities.

Safety and environmental regulation

Landlords are subject to a number of statutory duties that impact upon the condition of properties within the sector and their maintenance. The constellation of the provisions is 
largely focused on safety to the tenant or the wider community (as in where environmental regulation applies). Fig. 1 lists some of the main provisions that apply in addition to the HHSRS, although there is a measure of overlap between the two.

\section{Insert Fig. 1}

Fig. 1 Safety and Environmental Regulation applicable to the PRS 


\section{Further forms of control}

Some strategies develop a model of 'good practice' extending beyond safety protection. The Tenancy deposit scheme requires landlords to hold deposits in a Government-backed tenancy deposit scheme (TDP) if they rent properties on an assured shorthold tenancy that began after 6 April 2007. This information is now accessible to local housing authorities, by virtue of section 212A Housing Act 2004 as inserted by section 128 Housing and Planning Act 2016. In terms of regulatory style the approach marks arguably a more systematic attempt to construct the 'good' landlord. This (which Foucauldians may see as a form of governance, (Cowan, 2011)) seeks to adopt a more constitutive approach to defining the landlord in accordance with state ambition, often through a use of surveillance techniques in the form of information gathering, as the TDP provides. It suggests a shift in regulation, which moves from general protective measures to the further categorization and indeed de-aggregation of landlords within the sector into those considered 'good' and those 'bad'. It coincides with Government's stated intent to professionalize the sector and to, "crack down" on rogue landlords (written answers of April 2017 (W71404) and December 2017 (W120647)).

Constructing the 'rogue landlord'

The Housing and Planning Act 2016 introduced a raft of measures (many of which have yet to come into effect) relevant to housing. The provisions show some deference to the Joseph Rowntree Foundation's British Housing Report (1991) that recommended establishing an approved landlord system, that would enhance institutional investor confidence in the market. Part 2 of the Act deals with 'rogue' landlords and property agents, who target some of the most vulnerable in the sector by placing them in poorly maintained and overcrowded accommodation (DCLG, 2015, p.6). Interestingly the term, 'rogue landlord' is not defined but presumably will be construed from the activities undertaken. The provisions, which came into force on $6^{\text {th }}$ April 2018, enable local housing authorities to apply to a First-tier Tribunal for an order banning a landlord or their agent from letting housing in England or engaging in letting agency work, where they have been convicted of a "banning order offence". In its consultation of December 2017, it was proposed that banning order offences extend to a range of non-housing related offences including serious criminal offences and, potentially, immigration offences under the 'right to rent' provisions. Power is given also to the Secretary of State to compile a database of those made subject to a banning order. The Act empowers local authorities to impose civil penalties of up to $£ 30,000$ as an alternative to prosecution and for rent repayment orders to be made allowing tenants and local authorities to reclaim rent paid for a wide range of housing offences.

The idea of constructing the good landlord coalesces in the creation of the right to rent provisions. Under the Immigration Act 2014 (as amended) landlords must check the 
immigration status of prospective tenants before granting any residential tenancy agreement. If they fail to do so, they are subject to civil penalties and from December, 2016, criminal penalties of up to five years' imprisonment. Draconian as these measures are, the provisions seem to make private landlords 'proxies' for immigration officials and effectively co-opts them into the public regulatory space through the harnessing of their 'intelligence' on tenants' immigration status for much wider ends beyond the private housing sphere. By placing onerous requirements on landlords, they themselves potentially become, "the wrongdoer" given the penalties imposed. They posit the use of ex ante regulation, similar to the "prevent" strategy that prevails in other domains. The provisions also widen the scope of regulation within the sector, such they extend in objective well beyond the landlord tenant relation towards those focused on general immigration policy.

\section{Sketching the Emergence of a New Landlordism}

Inequalities do not rest solely as between landlord and tenant. They are present within the landlord sector and this intra-inequality informs the current regulatory trajectory. The Montagu Review (2012), considered the barriers to entry into the PRS by institutional investors. Encouraging institutional investment was seen as a way to improve the standing of the sector by offering longer term rented homes and a better standard of home to tenants. However negative fiscal changes in the Autumn statement of 2015 (announcing a three percentage point Stamp Duty Land Tax (SDLT) surcharge on additional residential properties over $£ 40,000$, including buy-to-let properties, from April and changes to Capital Gains Tax), seemed more explicitly to set out a change in policy emphasis away from institutional investment in the PRS.

As a House of Commons library briefing paper (2017) noted that,

With the significant majority of the existing PRS stock owned by individual investors, developing a 'new private rented sector' involves changes to individual landlord practice as well as the promotion of large-scale, professionally managed build-to-rent developments.

Successive governments' aim has been to make the transition from "cottage industry" to a professional sector offering high quality accommodation for rent. The result may be the existence of a differentiated sector not just in terms of types of housing but with regard to the type of landlord. A glance at the emerging regulatory trajectory in the PRS may show why. Policies such as the 'right to rent' and the categorization of the 'rogue' landlord have the 
stated aim of professionalizing the sector. Regulatory compliance scholars, drawing on the knowledge of criminologists, have shown that the spectrum of regulatory effectiveness is context dependent, and varies according to both the cost of the particular regime and the motivations of those the object of regulation ((Kagan and Scholz, 1984). Some being regulated will not internalize the required norms and instead will resort to or increase forms of deviance. With strategies to ban landlords under the 2016 legislation being highly dependent on local authority pro-active enforcement, in the absence of sufficient resources, 'rogues' are likely to remain in the system. Unlike the housing condition safety regimes, where landlords enrol experts to satisfy the requirements, the right to rent provisions harness the capacities of the landlord in the "offensive" against illegal immigration, thus operationalizing a policy agenda that bears little or no direct relation to the property or indeed the sector. Given the kaleidoscope of landlords present in the PRS, and their various motivations, ranging from being caring and concerned to do right, through to rank profit maximization, the prospect of non-compliance should not be overlooked. Further, the stigmatization of the amateur is something to be viewed with caution. Their presence is not necessarily adverse and amateurs can display ethical behaviours that some professionals lack. Those primarily motivated by profit may be those least likely to comply.

The shift towards categorisation of the landlord under the 'right to rent' provisions and the Housing and Planning Act 2016 relies upon a binary "right" or "wrong" or (in the case of the latter provisions, "good" or "bad"). However, given the variety of landlords present in the sector and the varying motivations for landlordism, the current regulatory style deployed could be highly problematic. There are known efficiencies for regulators in harnessing third party resources to secure their own ends, as law and economics scholars identify (Kraakman, 1986). However context is all important. The strategies deployed by Government appear to ignore the current structure of the housing market and the PRS in particular. A useful analogy here can be drawn with the configuration of supply chains and the role of intermediaries viz. those located between the supplier and ultimate the seller. Economists note that although the power relations within supply chains are affected by the capacities of those operating within a given market, this is not the only applicable rationale. The practices adopted by the parties within that market can be a significant variable. Those considered to have the power to take steps to consolidate (or indeed concentrate) or participate in practices that are restrictive can indeed distort the market. Similarly, the activities of those with the power to buy and those 'selling' are critical to understanding market behaviours and ultimately welfare. (Dobson and Waterson, 1999 p. 138). This knowledge has a significant effect on the efficiency and effectiveness of regulation. While it might be anticipated that Government could exert pressure over landlords, this may not necessarily be so using the supply chain analogy. 
Seeing the PRS as the equivalent of a supply chain by substituting the supplier, retailer and consumer for a state, landlord (private) and tenant 'chain' illuminates the nature of the regulatory problem. Although it has been posited that the 'retailer' (as an intermediate player) was dependent upon the manufacturer and thus lacking in market power, with markets being perfectly competitive, it has been shown that a presence of asymmetries in the relations creates barriers to entry (particularly in terms of licensing restrictions and the need for significant investment), damaging the credence of the hypothesis. The upshot is that retailers are not simply powerless agents of others and looking closely at the PRS housing market, it is possible to see something similar occurring. In some locations, concentrations of landlords, tenants and a scarcity of homes could subvert Government's capacities.

Where the regime is susceptible to a level of "noise" such that compliance costs are high (and these may not necessarily be monetary) pathologies can arise. The cultural baggage associated with the nature of property and ownership - whether mythical or real, (not to mention the significance attached to home ownership), can function to disrupt regulatory efficiencies because of the perceived increased social costs of compliance. This is aside from the assessment made by those landlords affected, who rightly or wrongly see the regime as one that imposes disproportionate or excessive financial costs (or as it may be termed, risk) could lead to the making of strategic decisions regarding non-compliance. In short, it may be rational not to comply given the vagaries of enforcement. It is not at all clear that in enforcement terms, regulators have sufficient resource capacities to enforce the current provisions.

Regulating landlord behaviour in the twenty first century perhaps marks the beginning of a watershed that, could alter the nature of landlordism and reshape the identity of the landlord. Fiscal measures (including the retention of capital gains rates for residential property that is not a main residence, the loss of the $10 \%$ 'wear and tear' allowance on furnished properties and the removal of mortgage interest payment deductions on buy-to-lets) together with increasing costs of regulatory could lead to a reconfiguration of the sector, with some small but dedicated landlords exiting it, because of rising transaction costs. The imposition of further duties impacts upon the sector as a whole and could lead to counterproductive results that could diminish supply.

The steps taken by Government to date bring with them the prospect of marginalizing, if not eliminating, those perceived to be acting against both tenants' interests. This is to be welcomed, if the provisions are enforced. However, requiring landlords to be agents of the state for the purposes of achieving wider policy ends - such as those relating to the 
monitoring and ultimately enforcement of immigration policy as the 'right to rent' does, is highly problematic. The increasing regulatory burden imposed upon landlords generally in the PRS (e.g. energy efficiency, fire safety, tenant deposits, right to rent) may lead to both enhanced "responsibilization" which is a good thing. The question however, is responsible to who? The significance of trust in maintaining co-operation and regulatory efficacy should never be overlooked (Braithwaite and Makkai, 1994). It is fundamental to the relations as between landlord and tenant. Distrust can impact upon regulatory compliance to the point of pathology (Gunningham and Kagan, 2005), with the sector being disrupted where enforcement is not effective and/or good landlords exit the market. The current direction of travel of state regulation of which the 'right to rent' provisions are the archetype, suggests Janus faced regulation - with landlords owing higher duties to state than those with whom they are in closer proximity and who are in need of housing. This displacing of the relations of trust as between landlord and tenant is surely neither desirable, or indeed, warranted. Further, in the quest to professionalize the sector, unintentionally replacing the amateur or accidental landlord, with a 'remote' professional could end in favouring larger providers in the market but may result in a perverse form of success that the Montagu Review could not achieve. Ultimately some of the systemic problems that have been witnessed historically and more recently unfortunately in the public sector may result. Without appreciating the general role of the law in regulating a drive to what may be termed the "new landlordism", it becomes difficult to even begin to suggest possible or, indeed, realistic solutions. This tension is manifested in both the current trajectory of regulation and its enforcement. At a more theoretical level, the provisions further confine the, 'privateness' in our understanding of private property in the PRS. 


\section{References}

Alexander G., (1998) 'Critical Land Law' in Bright, S. and Dewar, J., (eds) Land Law, Themes and Perspectives. OUP, Oxford.

Allen, J., (1983), "Property Relations and Landlordism - A Realist Approach" Environment and Planning D: Society and Space, Vol. 1 No. 2 pp. 191-203.

Allen, J, and McDowell, L., (1989) Landlords and Property: Social Relations in the Private Rented Sector. CUP, Cambridge.

Balchin, P., N. and Rhoden, M., (2002), Housing Policy: An Introduction, Routledge, London.

Blackstone, W., (1829), Commentaries on the laws of England: in four books with an analysis of the work /by Sir William Blackstone, Sweet, London.

Braithwaite, J. and Makkai, T., (1994) "Trust and Compliance", Policing and Society, Vol. 4, pp.1-12.

Bright, S. and Gilbert, G., (1995), Landlord and Tenant Law: The Nature of Tenancies. OUP, Oxford.

Commons, J. R., (1893), The Distribution of Wealth. Macmillan and Co., London.

Cowan, D., (2011), Housing Law and Policy, CUP, Cambridge.

Department of the Environment, (1978), National dwelling and housing survey, HMSO, London.

Department Communities and Local Government, (2010) Private Landlords Survey, HMSO

London.

Department Communities and Local Government, (2015) Tackling rogue landlords and improving the private rental sector. A technical discussion paper, HMSO London.

Department for Communities and Local Government,(2016), English Housing Survey:

Headline Report 2014-15, HMSO, London.

Department for Communities and Local Government (2017), Consultation on Proposed Banning Order Offences under the Housing and Planning Act 2016 Government Response, HMSO, London. https://www.gov.uk/government/uploads/system/uploads/attachment_data/file/670816/Bannin g_Orders_Consultation_Government_response.pdf $<1$ March 2018>

Derrida, J., (2002), Force of Law, The "Mystical Foundation of Authority", in Gil Anidjar (ed.) Acts of Religion., Routledge, London.

Davies, M., (2007) Property; Meanings, Histories, Theories, Routledge, Abingdon.

Desmond, M., (2016), Evicted Crown Publishers, NY.

Després, C., (1991), “The Meaning of Home”, Journal of Architectural and Planning

Research, Vol. 8 No. 2 pp. 96-115.

Dobson and Waterson, (1999), "Retailer power: recent developments and policy

implications" Economic Policy, Vol. 14 Issue 28, pp. 135-164.

Easthorpe, H., (2004), “A Place Called Home”, Housing Theory and Society, Vol. 21 No. 3, pp. 128-38.

Fox O’Mahony, L., (2006), “Conceptualizing Home: Theories, Laws and Policies, Hart Publishing, Oxford

Fox O'Mahony, L., (2013) “The Meaning of Home from Theory to Practice” Int'l Journal of the Built Environment. Vol. 5 No. 2 pp.156-71.

Fox O’Mahony, L., (2014) 'Property Outsiders and the Hidden Politics of Doctrinalism', Current Legal Problems Vol. 67 No. 1, pp. 409-445

Gray, K. (1991), "Property in Thin Air", CLJ Vol. 50 No. 2 pp. 252-307.

Gray, K. and Gray, S.F. (2008) Elements of Land Law, OUP, Oxford.

Gunningham, N. A., and Kagan, R. A. (2005), "Regulation and Business Behavior" Law \& Policy., Vol. 27 No. 2, pp. 213-18.

Gunningham, N. and Kagan, R., (2005) "Regulation and Business Behavior" Law and Policy Vol. No 2 pp. 213-218.

HM Treasury (2015) Spending Review and Autumn Statement 2015 Cm 9162 (November 2015). 
House of Commons Library Briefing Paper, (2016), Housing fitness in the private rented sector, No. 7328, available at: http://researchbriefings.files.parliament.uk/documents/CBP7328/CBP-7328.pdf (accessed 5 March 2018).

House of Commons Library Briefing Paper, (2017), Building the new private rented sector: issues and prospects (England) No. 07094, available at http://researchbriefings.files.parliament.uk/documents/SN07094/SN07094.pdf (accessed 9 June 2017). Housing, Communities and Local Government Committee, (2017) "Private Rented Sector Inquiry" (announced 12 October 2017), available at https://www.parliament.uk/business/committees/committees-a-z/commonsselect/communities-and-local-government-committee/inquiries/parliament-2017/inquiry1/ (accessed 9 February 2018).

Jackson, S., (1885), Landlord Abuses: and a plan for the extinction of landlordism, Wyman and sons, London.

Javid, S., (2017), "Theresa May to offer more security for renters", The Guardian, 4 February 2017 https://www.theguardian.com/society/2017/feb/04/may-abandons-home-owningdemocracy-thatcher-tories . (Accessed 3 March 2017).

Joseph Rowntree Foundation (1991) Inquiry into British Housing Second Report York. Joseph Rowntree Foundation (1993) The State of the Private Rented Sector Housing Research Findings No. 90, York.

Joseph Rowntree Foundation, (2006), Characteristics and Functions of the Private Rented Sector, available at. https://www.jrf.org.uk/report/characteristics-and-functions-privaterented-sector (Accessed 3 February 2017).

Kagan, R. A., and Scholz, J. T., (1984) "The Criminology of the Corporation and Regulatory Enforcement Strategies" in Hawkins, K. and Hingham, J. T., (eds.), Enforcing Regulation, Kluwer-Nijhoff, Mass.

Kemeny, J., (1981), The Myth of Home Ownership, Routledge and Kegan Paul, London. Kraakman, R., (1986), "Gatekeepers: The Anatomy of a Third Party Enforcement Strategy" Journal of Law, Economics, \& Organization, Vol. 2 No.1, pp. 53-104.

LawCom (2008) Housing: Encouraging Responsible Letting, LC 312, HMSO, London. Lazarus, H., (1892) Landlordism. General Publishing Company Ltd, London.

Macpherson, C. B., (1978) Property, Mainstream and Critical Positions, University of Toronto Press, Buffalo.

Mallett, S., (2004), "Understanding Home: A Critical Review of the Literature", Sociological Review, Vol. 52 No. 1, pp. 62-89.

Mellor, R., (1979), Urban Sociology in an Urbanized Society, Routledge and Kegan Paul, London.

Merrill, T. W. (1998), "Property and the Right to Exclude" Neb. L. Rev. Vol. 77 No. 4 pp.730-755

Merrill, T. W. and Smith, H. E., (2014), "Why Restate the Bundle? The disintegration of the Restatement of Property" Brooklyn Law Review Vol. 79 No. 2, pp. 681-708.

Montagu Review, (2012), Review of the barriers to institutional investment in private rented homes (August 2012) Department for Communities and Local Government, HMSO, London Nelken, D., (1983), the Limits of the Legal Process: A Study of Landlords, Law and Crime, Academic Press Inc. London and NY. ONS (2016) ONS Housing Statistics, https://www.gov.uk/government/uploads/system/uploads/attachment_data/file/532220/Housin g_Statistics_June 2016.pdf (Accessed 3 March 2017).

Osborne, D. and Gaebler, T., (1992) Reinventing government: how the entrepreneurial spirit is transforming the public sector, Addison-Wesley Pub. Co, Reading Mass.

Peñalver, E. M. (2006), "Property Metaphors and Kelo v. New London: Two views of the Castle", Fordham Law Rev. Vol. 74 No. 6, pp. 2971-2976.

Prudhon, P-J., (1876) What is Property? an inquiry into the principle of right and of government, translated from the French by Benj. R. Tucker, Princeton University Press, Princeton, NJ. 
Renner, K., (1949) The Institutions of private law and their social functions, Routledge and Kegan Paul, London.

Roark, M., (2017) "Under-Propertied Persons", Cornell Journal of Law and Public Policy, Vol. 28 No. 1, Available at SSRN: https://ssrn.com/abstract=2918598 or http://dx.doi.org/10.2139/ssrn.2918598.

Resolution Foundation , (2017) Homes sweet homes - the rise of multiple property ownership in Britain. 19 August 2017. http://www.resolutionfoundation.org/publications/the-generationof-wealth-asset-accumulation-across-and-within-cohorts/ $<3$ January 2018>.

Robinson, M., (2008), Home, Virago, London.

Ronald, R. and Kadi, J., (2017) "The revival of private landlords in Britain's posthomeownership society" HOUWEL Working paper 9, Centre for Urban Studies, University of Amsterdam, February 2016.

Ronald, R., Lennartz, C. and Kadi, J., (2017), "What ever happened to asset-based welfare? Shifting approaches to housing wealth and welfare security”, Policy \& Politics, Vol. 45 No. 2, pp. 173-93.

Scanlon, K. and Whitehead, C., (2106), The Profile of UK Private Landlords, CML Research, Council of Mortgage Lenders, London.

Selznick, P., (1985). "Focusing organizational research on regulation." in Roger Noll (ed). Regulatory Policy and the Social Sciences (pp. 363-367). University of California Press, Berkeley, Ca.

Shelter (2017) Improving Private Renting, http://england.shelter.org.uk/campaigns /why we campaign/improving private renting (Accessed 9 March 2018).

Simcock, T. J., (2017). State Intervention into Renting: Making sense of the impact of policy changes. Residential Landlords Association, Manchester. Available from:

https://research.rla.org.uk/wp-content/uploads/state-intervention-into-renting-2017-report.pdf Singer, J. W., (2002), Property Law: Rules, Policies and Practices, Aspen Publishers, Co. Smith, H. E., (2012) "Property as the Law of Things" Harvard Law Review Vol. 125 No. 7 , pp. 1691-1726.

\section{Cases}

‘Semayne’s Case' (1604) Coke Rep., 5, pp. 91(a)-93(a). 
Fig. 1 Safety and Environmental Regulation applicable to the PRS

\begin{tabular}{|c|c|c|}
\hline & Legal provision & \\
\hline Gas Safety & $\begin{array}{l}\text { Gas Safety (Installation and Use) } \\
\text { Regulations 1998, SI 1998/2451 }\end{array}$ & $\begin{array}{l}\text { Regulation 36: General duties of landlords to ensure that gas fittings and } \\
\text { flues are maintained in a safe condition (Reg. } 36(2) \text { and to secure annual } \\
\text { checking for safety of gas appliances and flues by CORGI Registered } \\
\text { engineers. Record of checks provided to tenant. Infringement } \\
\text { constitutes an offence carrying a fine of up to } £ 20,000 \text { or imprisonment } \\
\text { or both. }\end{array}$ \\
\hline $\begin{array}{l}\text { Electrical } \\
\text { Appliance } \\
\text { Safety }\end{array}$ & HHSRS & $\begin{array}{l}\text { HHSRS covered (PAT testing advisable). Prospective duties contained } \\
\text { in the Housing and Planning Act } 2016 \text { s122 similar to gas safety }\end{array}$ \\
\hline $\begin{array}{l}\text { Smoke and } \\
\text { Carbon } \\
\text { Monoxide } \\
\text { Alarms }\end{array}$ & 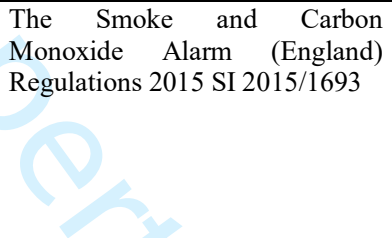 & $\begin{array}{l}\text { From } 1 \text { October } 2015 \text { to have at least one smoke alarm installed on every } \\
\text { storey of their properties and a carbon monoxide alarm in any room } \\
\text { containing a solid fuel burning appliance (eg a coal fire, wood burning } \\
\text { stove). After that, the landlord must make sure the alarms are in working } \\
\text { order at the start of each new tenancy. Enforced by local authorities who } \\
\text { can impose a fine of up to } £ 5,000 \text { where a landlord fails to comply with } \\
\text { a remedial notice. }\end{array}$ \\
\hline $\begin{array}{l}\text { Legionella } \\
\text { exposure }\end{array}$ & $\begin{array}{l}\text { S3(2) Health and Safety at Work } \\
\text { Act } 1974 \text { (HSWA) applied by s } \\
53 \text { HSWA applying the Control } \\
\text { of Substances Hazardous to } \\
\text { Health Regulations } 2002 \\
\text { (COSHH) }\end{array}$ & $\begin{array}{l}\text { It shall be the duty of every self-employed person to conduct his } \\
\text { undertaking in such a way as to ensure, so far as is reasonably } \\
\text { practicable, that he and other persons (not being his employees) who } \\
\text { may be affected thereby are not thereby exposed to risks to their health } \\
\text { or safety. }\end{array}$ \\
\hline $\begin{array}{l}\text { Energy } \\
\text { Efficiency }\end{array}$ & $\begin{array}{l}\text { Energy } \\
\text { Efficiency (Private Rented } \\
\text { Property) (England and Wales) } \\
\text { (Amendment) Regulations } 2016 \\
\text { SI 2016/660 }\end{array}$ & Minimum level of energy efficiency standard (EPC E) \\
\hline Fire Safety & $\begin{array}{l}\text { Regulatory Reform (Fire Safety) } \\
\text { Order } 2005\end{array}$ & $\begin{array}{l}\text { Duty to take general fire precautions as may reasonably be required to } \\
\text { ensure that premises are safe where a prohibition notice has been served }\end{array}$ \\
\hline
\end{tabular}

